\title{
Perceptions of Indonesian Teachers and Students on the Use of Quipper School as an Online Platform for Extended EFL Learning
}

\author{
Eliasanti Agustina \\ Graduate Program in ELT, Universitas Negeri Malang, Indonesia \\ Bambang Yudi Cahyono \\ Universitas Negeri Malang, Indonesia
}

\begin{abstract}
In Indonesia, the globalization era has directed the policy makers to establish English as a compulsory subject in the secondary school curriculum. However, the major issue in pursuing the goal of the teaching of English as a foreign language (EFL) has been the imbalance between the amount of teaching materials and the time to teach the materials. The availability of the Internet has provided a concept that learning is not just a one-time event to be conducted at schools, but learning is also a continuous process that can be conducted beyond the school time. One of the learning platforms in the Internet is Quipper School, and this platform has been used by EFL teachers in Indonesia. This article reports the result of research on the EFL teachers' perceptions on the teaching of EFL and the reasons for using Quipper School as a platform for the students' EFL learning. Three EFL teachers teaching in senior high school level and six students who have used the platform with the three teachers were involved in this research. The results of the study show that the Indonesian EFL teachers used the platform not only for coping with the limited time available for EFL teaching, but also due to the significant value of the platform to support the students' EFL learning.
\end{abstract}

Index Terms-Qupper school, EFL teachers, online platform, extended EFL learning

\section{INTRODUCTION}

In Indonesia, English has been established as a foreign language (EFL) and taught in secondary schools.Outside the schools, the students use Indonesian as a national languageor vernaculars for communication with people from the same regions or islands. This means that the only English exposure EFL students may get is in the schools. Unfortunately, with the application of the 2013 curriculum, Indonesian secondary school students learn English only for two lesson hours a week (45 minutes $\mathrm{x}$ 2). This condition leads to an issue towards the lack of time in English teaching and learning process. Students do not get enough time to learn English so they might get problem in the process of mastering EFL. The time limitation forces the English teachers to put students' understanding on the second place. They tend to put more attention on how to cover all materials in the limited time in a semester. One way to cope with the shortage of time, some teachers turn into the role of technology.

One of the recent technologies applied in language classroom is Quipper School. It aims to empower teachers to help their students by combining quality learning content with an advanced online platform. The platform also provides practical experience for students in using technology in their daily life. It has two kinds of portals namely teacher (or tutor) portal and student portal. Each portal has different functions and benefits. Particularly, for English subjects, Quipper School covers materials which focus on the English skills, namely, listening, speaking, reading and writing. Accordingly, we assumed that the shortage of time for EFL learning in Indonesian secondary schools could possibly be solved by adopting the advantages offered by integrating English learning with Quipper School as an extended learning platform.

\section{LITERATURE REVIEW}

Nowadays, school students who were born from 1998 up to 2001 are categorized to generation Z (Robinson, 2016). Generation Z is generation of people who were born between 1995 and 2015. They are of the Internet generation, digital native people. They are fluent gadget users. Moreover, they rely much on their gadgets. They use their smart phone not only as communication aid but they also use it in most aspects in their everyday activities such as playing music, browsing, watching videos, doing assignments, online shopping, or playing games. It is even impossible to forbid them not to operate their gadgets in the classroom. Linked to the phenomena above, it is better for English teachers to integrate technology in the teaching and learning process so the students can maximize the use of their gadgets in the class for good purposes to support their learning. Cook (2015) suggested teachers adopt technology in teaching generation $\mathrm{Z}$ and stay connected all the time. 
Our review of research reports showed that EFL teachers have utilized technologiesfor English learning such as Power Point, Video, Electronic dictionary, Blog, Facebook, Skype, and Edmodo. In addition, our review on previous studies showed that integrating technology in EFL learning creates some positive effects. Banados's (2006) results of research indicated that students involved in technological rich classroom showed a remarkable improvement in speaking skill and improvements in all other language skills(listening, reading, and writing) and language components, especially in pronunciation, vocabulary and grammar. A research study conducted by Ahmad (2012) shows that integration of media and technology to the class can boost students' participation, promote student-centered mode, create positive atmosphere, and improve the students' writing ability. Kamnoetsin (2014) found that Facebook helped to break space-time constraints and provided pleasant experiences, improved students' writing skills including grammar and vocabulary. Thus, Facebook served as an efficient means to facilitate learning process by providing important English knowledge and eased the students in sharing knowledge

Some studies focused on the students' attitudes towards the implemention of technology in English classroom. Leakey and Ranchoux (2006) found that blended CALL (Computer-Asssisted Language Learning) made students respond more positively toward the learning process and they prefer this approach to the traditional class. Lin's (2003) research showed that the majority of Taiwanese EFL learners had positive attitudes towards the use of multimedia resources in their language program. They were motivated to extend their language abilities by surfing the Internet, to record and save their own writing and to make use of multimedia resources for developing their reading skills. Suthiwartnarueput and Wasanasomsithi's (2012) research revealed that students had positive attitudes towards the use of Facebook as a means of learning grammar and writing. As an alternative learning tool, Facebook provided them a convenient and attractive means to be involved in discussions with the teacher and other users who had better grammatical knowledge.

Previous studies have shown positive sides about integrating technology for ELT. Unfortunately, a study about the application of Quipper School in ELT context is still a rare occasion. Therefore, this study attempts to fill the gap by providing the data about the way of English teachers and students implement Quipper School as their supplementary English learning. It aims to investigate the perceptions of Indonesian teachers and students on how Quipper School can be implemented as an online platform for extended EFL learning. This study is significant as it attempts to provide a means to make up the shortage of time in the EFL teaching and learning in Indonesian secondary schools. (www.quipperschool.com)

\section{METHOD}

In this study, we use a descriptive qualitative design to examine the perceptions of teachers and students on the implementation of Quipper School as an online platform for extended EFL learning. The subjects of the study were three English teachers and six students of a senior high school at Mojokerto City which is located in the Province of East Java, Indonesia. Best and Khan (1993) stated that care in selecting sample is more important than in increasing the size of the sample. They argue that in qualitative approach the authority of the subjects are given more emphasis over the amount of the samples.

Each of the teachers involved in this study, who is addressed by using pseudonyms, taught students from different grades. Mr. Ary taught Grade XII students; Ms. Merry taught Grade XI students; and Ms. Terry taught Grade X. Each teacher has different length of experience in teaching EFL as shown in Table 1.

TABLE 1

TEACHERS' DATA

\begin{tabular}{lll}
\hline Name & Teaching Experience & Grade Taught \\
\hline Mr Ary & 20 years & 12 \\
Ms Merry & 18 years & 11 \\
Ms Terry & 9 years & 10 \\
\hline
\end{tabular}

It can be seen from the table that the teacher subjects have different years of teaching experience. In addition to the teachers, two students from each grade were involved in this study.

Instrument is a tool used to collect data in order to conduct any research (Ary, Jacobs, \& Sorensen, 1985: 71). To collect the data for this research, we used one instrument, the interview guide. The interview guide is semi-structured, meaning that it is not a fixed form of interview questions. Interviews were be conducted with the English teachers and students (see the Interview Guides in Appendices 1 and 2). For this research, we analyzed the data in several steps as proposed by Miles and Huberman (1994). The steps include data reduction, data display, data verification, and conclusion.

Through the process of interview, we obtained the data in order toachieve the research objectives. It should be noted that observation of the practice in using Quipper School was not conducted because the platform was used in the process of extended learning outside classroom. However, we tried to cross-check the teachers' data by conducting interviews with the students. The questions included in the interview refer to the subheading presented in this section and arranged conforming to the precise order. 


\section{RESULTS}

The results of the study are presented in two parts: teachers' perceptions and students' perceptions on the use of Quipper School as online platform for extended EFL learning.

\section{A. Teachers' Perceptions on the Use of Quipper School}

The teachers were asked to inform how they perceive about some aspects regarding the implementation of Quipper Schoolas an online platform for extended EFL learning. The aspects include whether or not they applied Quipper School, used Quipper School to choose materials, and used Quipper School to create materials. In addition, they were also asked whether they think Quipper school eases their jobs, solves problems of time shortage, and there is an obstacle in the implementation. The teachers' answers to the questions are shown in Table 2.

TABLE 2

TEACHERS' PERCEPTION ON THE USE OF QUIPPER SCHOOL

\begin{tabular}{llll}
\hline \multirow{2}{*}{ No } & Statement & Responses & \\
\cline { 2 - 4 } & Applying Quipper School in English learning & $\sqrt{ }$ & Ms. Merry \\
\hline 1 & Choosing material in Quipper School & $\sqrt{ }$ & Ms. Terry \\
2 & Creating material in Quipper School & $\sqrt{ }$ & $\sqrt{ }$ \\
3 & Quipper School can ease teacher in teaching and learning process & $\sqrt{ }$ & $\mathrm{x}$ \\
4 & Quipper school can solve the problem about lack of time & $\sqrt{ }$ & $\mathrm{V}$ \\
5 & There is obstacle when implementing Quipper School & $\mathrm{V}$ & $\sqrt{ }$ \\
6 & & & $\sqrt{ }$ \\
\hline
\end{tabular}

(1) The Use of Quipper School as an Online Platform

With regard to the use of Quipper School as an online platform, Mr Ary, a senior teacher in this school, agreed that the features of Quipper School were truly beneficial in coping with the lack of time in teaching English. As a pioneer, he initiated and encouraged other teachers to use Quipper School as extended learning platform. As a teacher who played many roles, he sometimes was absent to teach. He said "I sometimes cannot teach because of some reasons, but it is not a problem as I can rely on the use of Quipper School. I can pick the exercises for the students and also the deadline. 'Therefore, he made up the materials and had the remedial instruction by using Quipper School. The students whose scores were under the minimum criteria of mastery (MCM) were given an additional test or assignment through Quipper School to add their scores in order to reach the MCM.

Ms Merry stated that she often integrated technology in teaching. More particularly, she used Quipper School outside classroom for three times. She chose to use Quipper School because many of the students needed to do more exercises outside classroom to improve their understanding of the material. She reckoned that the amount of materials in English subject established in the curriculum had no balance with the amount of time allotment set by the government. She felt that it was impossible to cover all the materials in one semester without extra activities for the students. Accordingly, in addition to the time for classroom instruction, she asked the students to practice beyond the school hours to improve their listening ability. In her opinion, it was good to give the students additional assignments through Quipper School to help students learn the targeted materials.

Ms Terry, the other teacher interviewed for this study, usually used Quipper School fora post-learning activity, She asked the students to do exercises based on what they had learned. When the time was not enough to explain a particular topic, she asked the students to continue learning through Quipper School. Furthermore, before mid-term of final term examinations, more grammar-related exercises or reading passages were normally provided in Quipper School for the students to study independently at home.

(2) Selection of Materials and assignments in Quipper School

In the case of material selection, Mr Ary emphasized that he would not give difficult exercises because to the students. He stated that the intention to give exercises is to drill the students due to time limitation for classroom learning. He selected the materials on the basis of the instructional objectives and the topic discussed in the class. He argued that this was just extended learning which took place out of obligatory hours so that he only took the exercises from Quipper School.

Ms Merry had some considerations in selecting the learning materials to be included in Quipper School. She selected the materials on the basis of the topic the students have discussed. She thought if the students need extra exercises in comprehending one grammatical topic such as tenses, she would provide it through Quipper School to catch-up the time. She said, "I simply choose exercises from Quipper School as students' homework. The materials have been explained in the classroom". She did not make detail considerations on whether the materials contain some cultural information or not, or provide meaningful content, or use the standard English, but she ensured that the exercise is in accordance with the student's level of proficiency. In addition, she tended to combine the materials that she already has with some other materials rather than to create or adopt it.

Ms Terry clarified that she selected materials in Quipper School which were appropriate with the students' level of proficiency. She argued that with heavy workloads in the school and additional job as an English private tutor, she did not create new materials. She also explained that a lot of understandable materials are available Quipper School. Furthermore, she stated that it was easy to select materials and match the, with the topic that is discussed. 
(3) Features of Quipper School and Obstacles in the Implementation

Quipper School is known to be different from other existing learning websites because of its features that enable teachers to analyze the students' scores. Mr Ary found that he could ascertain the range of the students' scores and monitor the progress of students' outcomes. He can also analyze the scores lower than the MCM as the consideration for giving students remedial assignments. Then the scores can be processed to determine the final scores of the students.

Ms Merry thought that Quipper school is a comprehensive learning website. For example, Quipper School outperforms Edmodo as the latter does not provide any score analysis and feedback provision. She said "Score analysis provided by Quipper School helps me, as the teacher in knowing the condition of my students and be the source of reflection.'Thus, Quipper School offers various materials based on the topic.All participants contended that finding materials via the Internet could be risky because of the abundance. To select which materials are trustworthy and feasible to use would be very time-consuming.

Accordingly, equipped by those special features, the teacher participants perceived that this learning website could cope with the shortage of time in learning English in the classroom. The four required skills in learning English are arduous to be realized in 2 hours of lesson in a week. Hence, one of teacher participants divided those four skills into listening and reading material and exercise were given through Quipper School meanwhile speaking and writing skill which required intensive guidance by the teachers would be carried out in the classroom. Listening skill which is highlighted by all participants to be difficult to undertake in the classroom is sustained by the feature of Quipper School. The flexibility of Quipper School that can be accessed with smartphone or laptop allows the students to do the assignments whenever and wherever they want.

On the other hand, the obstacles in the implementation of Quipper School were found as well. One major problem that is highlighted by teacher participants is incapability in controlling the reliability of the students' scores. Ms Merry and Ms Terry suggested not to rely on the scores derived from assignments given through Quipper School. Since working the assignments through Quipper School is outside the school hours, the teachers cannot monitor how the students work on it. Commonly, the assignment given through Quipper School is in the form of multiple choice. This kind of test is known to be low in validity because it only requires students to memorize or guess the stems. Students are also more likely to cheat on the answers by copying the other students' answers. Ms Merry said that it is better to combine the scores derived from assignments given through Quipper School with the scores derived from other assignments, project. She added that emphasized that it was important to judge on the students' process rather than the final product.

It is important to note that the teachers perceived that the students tended be tricky as they outperform the teachers in terms of the use of technology. The students are digital natives as they relied on gadget, social media, and the Internet. Meanwhile, the teachers are digital migrants who struggle to move from the old era to the digital era whereby all the aspects of life can be integrated with technology especially on their field, TEFL. Thus, the biggest obstacles are perceived by the technologically illiterate teachers. In broad sense, Quipper School cannot be massively implemented if the teachers who are supposed to be technologically literate seem to be against the integration of technology with learning.

\section{B. Supports from the Students' Perception}

To complete the whole view about the use of Quipper School, the researchers added different perspectives from the students to confirm what the participant teachers had revealed. Besides, Quipper School not only can be accessed by the students only if the teacher requests them to do but also the students can access any material whenever they want and wherever they are. Mostly, the students answered that they would access Quipper School when the teacher gave them homework, assignment for score remedial, assignment due to the teacher is away or exercise as preparation for test in Quipper School. The material that could not be discussed in the class due to limited time would be given through Quipper School in the form of summary from the teacher. On the other hand, two of six students who got a chance to be interviewed confessed that they never accessed Quipper School by their own initiative. The rest of participants said that they did access Quipper School because they perceived that they needed more exercises that were not provided in the textbook.

Based on the students' perspectives, one of features from Quipper School which enable students to know their score and its analysis, can be a motivation for them to learn from their mistakes. The notification not only provides the score of the students but also the feedback. Therefore, the students realized about their strengths and weaknesses after doing the assignments. The feedback from the teachers is very helpful for them in terms of giving explanation why they did it wrong so that they can learn from the mistakes and would not do the same thing in the future. Besides, the score analysis helps them to be aware of their achievement. Knowing this information, the students admitted that they could maintain their achievement in order to avoid declining. They all agreed that this feature increased their motivation in learning. In fact, feedback can be obtained not only from the teacher but also from the students. The feature in Quipper School allows the students to communicate and have discussion with other students related to the assignments via Quipper message.

One student participant said that if she had not understood the material yet then she would log-in her Quipper School account to do some more exercises. The problem was revealed from student's perspective when using Quipper School is bad internet connection. It is the only obstacle in using Quipper School. There is no problem coming from the 
Quipper School itself but the external factor that is supposed to support it. If they have to do the assignments in their house, for instance, they will get trouble if the area in which they live does not have smooth internet connection.

\section{DISCUSSION}

The analysis of the responses of the teachers and the students showed that Quipper School can be used as an online platform for extended EFL learning. As an online platform,Quipper School can be used either in the classroom or outside the classroom. Because of the limited time allocation for EFL learning in the classroom, all the teachers thought that Quipper School would be best applied for extended EFL learning beyond the classroom. All the teachers agreed that Quipper School helped them in various ways such as providing materials for exercises and assignments as well as providing tools for score analysis. Generally, Quipper School is beneficial for EFL learning. Based on the findings, either teachers or students perceived that Quipper School is helpful to support the mastery of English skills. More particularly, Quipper school is beneficial for practicing listening and reading skills.

In the process of selecting the materials or assignments, it is impossible to escape from the things that need to be considered in the process. The consideration of selecting materials and assignments is pivotal principal that McDonough and Shaw (1993) point out. They stated that the ability to evaluate and supplement teaching materials effectively is a very important professional activity for EFL teachers and needs to be conducted continuously. All participants tended to select material based on the topic of the meeting rather than selected the materials in accordance with the theory of material selection.

The Investigation of the pattern of material selection showed that the teachers tended to adapt the materials rather than to adopt or to create materials. The teachers tried to match the materials to the students' level of proficiency. The adoption of materials was aimed to reduce the students' difficulties in working on the materials. Kitao\& Kitao (1997) said that it is better to provide assignment that is slightly higher in their level of difficulty than the students' current level of English proficiency. An important thing that cannot be slipped in selecting materials are the relevancy between the content and the students' age or cultural background (Charalambous, 2011). If adapting the material is enough to obtain reliable material and assignment then the teachers did not really have to create it anymore. Material and assignment given through Quipper School is just supplementary and continuation of the series of learning activity. As a matter of fact, the shortage of time doesn't only exist in English learning but also in creating the materials.

All the barriers and features should correspond very well. The teachers are supposed to be creative in handling the problems related to the use of Quipper School as an online platform for extended EFL learning. This practice cannot be considered to be formal blended learning which arranges the balance amount between face-to-face learning and online meeting. Blended learning is rooted in the idea that learning is not just a one-time event-learning is a continuous process (Singh, 2003). We assumed that this kind of implementation is variation of learning activities which are used by the teachers to cover the shortage of time or to solve the unexpected situation. Accordingly, the major barriers perceived by the teachers deals with the reliability of the assignments.

\section{CONCLUSION}

This article has presented the results of analysis on the use of Quipper School as an online platform in extended EFL learning. Briefly stated, all of the teachers have impelemented Quipper School as a means of extended EFL learning for more than a year. The capability of Quipper School in providing liable materials eases the teachers and students in coping with limited time.Score analysis, deadline setting, trustworthy materials and feedback provision are believed to be some of the benefits that can be earned from Quipper School. Moreover, this platform can also be used by all English teachers and learners who need additional learning materials and exercises. Based on what were presented, the teachers felt unimpeded in terms of giving extra exercises to the students even if they couldnot be taught in the classroom. In addition, the students were motivated to learn English through Quipper School especially for practicing listening skill since the limitation of time made them unable to practice listening in the classroom. However, the incredulity of the teachers relying on the scores derived from the assignments given through Quipper School is not supposed to be barriers in implementing Quipper School. Given that there are more benefits offered by the use of Quipper School, the teachers should remain considering that this website is worth using particularly in terms of giving more exercises in a limited time. In relation to blended learning, this practice cannot be considered entirely blended learning course since the use of Quipper School is only carried out in the moment when the teachers need it in order to catch up the time and materials. Besides, it is not part of the curriculum whereby all the schools are obliged to implement it. Yet, it is an evidence of good practice performed by the teachers in handling the issues encountered during the teaching and learning process.

\section{APPENDIX 1. INTERVIEW GUIDE USED WITH THE TEACHERS}

1. Do you know about Quipper School?

2. Have you ever applied it in the English learning?

3. In what occasion do you usually ask your student to access their Quipperaccount?

4. Do you design your own material in the Quipper School or simply select it? 
5. How do you select or design the material in the Quipper School?

6. Does Quipper School ease you in the teaching and learning process?

7. If so, in what way?

8. Does the platform help you to combat a problem about lack of time?

9. Do you like using Quipper school? Why?

10. Do you find any obstacles when implementing Quipper School?

11. Is there anything that should be improved from Quipper School?

12. Do you have any suggestions for English teachers who want to apply Quipper School?

\section{APPENDIX 2. INTER VIEW GUIDE USED WITH THE STUDENTS}

1. Do you know about QuipperSchool?

2. Have you ever applied it to learn English?

3. In what occasion does your teacher ask you to access your QuipperSchool?

4. Have you ever accessed your Quipper School because of your own need? Why?

5. Does QuipperSchool help you in learning English?

6. If so, in what way?

7. Do you learn English more using Quipper School?

8. Do you like Quipper School? Why?

9. Do you find any difficulties while you are using Quipper School?

10. Is there anything that should be improved from QuipperSchool?

\section{REFERENCES}

[1] Ahmad, J. (2012). English language teaching (ELT) and integration of media technology. Cyprus International Conference on Educational research (CY-ICER-2012) 47, 924-929.

[2] Ary, D., Jacobs, C.,L., \& Sorensen, C. (2010). Introduction to research in education ( $8^{\text {th }}$ ed). Belmont, CA: Wadsworth, Cengage Learning.

[3] Banados, E. (2006). A blended-learning pedagogical model for teaching and learning EFL successfully through an online interactive multimedia environment. CALICO Journal 23(3), 533-550.

[4] Best, J., W., \& Kahn, J. V. (1993). Research in education.( $8^{\text {th }}$ ed). America, Ally \& Bacon.

[5] Charalambous, A., C. (2011). The role and use of course books in EFL. http://files.eric.ed.gov/fulltext/ED524247.pdf (accessed 23/12/2016).

[6] Cook, V. (2015). Who are the faculty and who are the students in 2015?. University of Illinois Springfield. $\mathrm{https} / / /$ sites.google.com/a/uis.edu/colrs_cook (accessed 11/11/2016).

[7] Kamnoetsin, T. (2014). Social media use: A critical analysis of facebook's impact on collegiate EFL students' English writing in Thailand. New Jearsey: Seton Hall University Dissertation and Theses.

[8] Kitao, K. \& Kitao, K. S. (1997). Selecting and Developing Teaching/Learning Materials. The Internet TESL Journal 4(4), 1. http://webcache.googleusercontent.com/search?q=cache:http://202.194.48.102/englishonline/jxyj/iteslj/Kitao-Materials.html (accessed 3/4/2017).

[9] Leakey, J., \& Ranchoux, A. (2006). BLINGUA: A blended language learning approach for CALL. Computer Assisted Language Learning 19(4), 357-372.

[10] Lin, A. (2003). An initial study on EFL Learners' attitudes towards multimedia application in language learning. Teaching English with technology 3(2). www.tewtjournal.org/VOL\%203/ISSUE\%202/01_ANINITIALSTUDY.pdf (accessed 2/10/2016).

[11] Miles, M. B., \& Huberman, A. M. (1994). Qualitative data analysis: An expanded sourcebook. London: SAGE Publications Inc.

[12] Quipper School - Layanan E-learning gratis! [Free E-learning service] http://www.wirahadie.com/2015/03/quipper-schoollayanan-e-learning-gratis.html. (accessed 4/8/2016).

[13] Robinson, M. T. (2016). The generations: What generations are you? www.careerplanner.com (accessed 20/11/2016).

[14] Singh, H. (2003). Building effective blended learning programs. Issue of Educational Technology 43(6), 51-54. Retrieved http://asianvu.com/bookstoread/framework/blended-learning.pdf (accessed 15/1/2017).

[15] Suthiwartnarueput, T., \& Wasanasomsithi, P. (2012). Effects of using facebook as a medium for discussion of English grammar and writing of low intermediate EFL students. Electronic Journal of Foreign Language Teaching 9(2), 194-214.

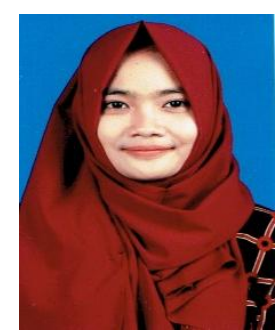

Eliasanti Agustina is a student in Graduate Program in English Language Teaching at Universitas Negeri Malang, East Java, Indonesia. She obtained her Bachelor degree in English Language Teaching from 2015. Email: elia.zenfone5@gmail.com 


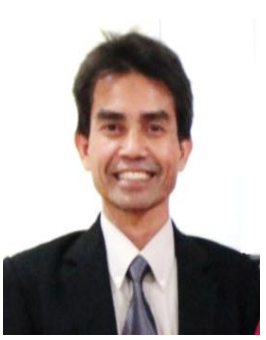

Bambang Yudi Cahyono is a Professor in Applied Linguistics at Universitas Negeri Malang, East Java, Indonesia. He earned his MA degree from Concordia University, Montreal, Canada and PhD from the University of Melbourne, Australia. E-mail: yudic2000@yahoo.com 